\title{
Double Vision in Browning's Meeting at Night and Parting at Morning
}

\author{
Lihua Zhang \\ School of Foreign Languages, Beijing Institute of Technology, Beijing 100081, China
}

\begin{abstract}
This paper, focusing on the two short poems of Robert Browning, Meeting at Night, and Parting at Morning, with the help of the perspective of double vision, studies the double self reflected in these two short poems, what the narrator wants to do internally, and what he is supposed to be socially; and the connotations imposed by the features of this particular historical period, Victorian Era.
\end{abstract}

Index Terms - double vision, Victorian era, poetry

\section{DOUBLE Vision AND Victorian POETRY}

The Victorian Era is that of patriarchal regime, middle-class moral aesthetic, and "faith in honest doubt" as Matthew Arnold called it, as well as that of material prosperity and technological advancement. It was conservative in morality and social life, upholding the banner of "utilitarianism" and presenting the image of responsible citizens to the public. People then had a strong responsibility for family with family as the moral basis. It thought a perfect family was one which had many family members. The middle-class family thought it was an honor to have lots of children. It is in this era that the middle-class woman and man came to be called "lady" and "gentleman": the former was supposed to be docile, sweet and submissive while the latter was the genuine dominant force in life. In this context, the Victorian poetry was much a middle-class discourse and poets then were the moral forces, prophets and teachers just as David G. Riede (2005) commented: "Poetry became... a hoped-for means of universalizing middle-class values, and especially of extending them to the lower classes - the majority of the British population, which was becoming increasingly restive and influential with the gradual spread of democracy." (p.426) In other words, the taste of the Victorian Era is "applied" poetry against "pure" or "absolute" poetry in the sense that poetry should be useful, either to teach moral lessons - the middle-class value system, or to entertain socially — pastime for the middle-class.

Meanwhile, the Victorian Age is also that of the unrest and uncertainty with flooding of ideas pounding over people's minds intensely, a "damned vacillating state" as Tennyson called it. The publication of Charles Darwin's The Origins of Species and The Descent of Man undermined traditional religious faith. It is proved that Bible was not the direct word of God; instead, it was a collection of texts from diverse cultures. There were no longer unifying absolutes to integrate and internalize knowledge in a coherent worldview. This lack of a controlling master discourse, together with Victorian sexual regression, produced anxiety and consequently made a subtle undercurrent of private vision where man is either violently aggressive or nostalgically intoxicated in his ideal dream-like world, as opposed to the respectable public self. In poetic creation, poets, on the one hand, meet the moral expectation to articulate a publicly accepted voice, and on the other hand, rebel against the public voice with a privately audible voice to give artistic self-expression and self-indulgence.

This division between the private one and the public one is indeed a prevailing theme in the Victorian Era, attributed to the rapid advancement of science which is empirical and rationalistic in method: division between conscious and unconscious; between intellect and imagination; between external world and internal world; between soul and body; between public vision and private one; between his commitment and his pensive world; between responsibilities and self-expression and self-indulgence. Rejecting the prevailing notion that poetry served the moral instruction and anything useful, Aesthetic movement concentrates on the "pure art", treating poetry as an independent art form.

"The major poets did not abandon either the idea of art as introspective and self-expressive or the commitment to write for the moral edification of their contemporaries, although they struggled to reconcile these somewhat incompatible ambitions." (David, 2005, p.427) In Tennyson's poem The Lady of Shallot Shallot's curse actually denotes early Tennyson's aesthetic view that art is autonomous to be separated from the bustling real world, but meanwhile he is supposed to fulfill his duty within the real world. His art is his life, and his life is his art, and his private vision is all that counts. It is the same to Robert Browning. The comment on Tennyson's poetry by David G. Riede is appropriately an accurate crystallization of Browning's poetry: "The representation in these poems of the aesthetic temperament as female suggests a division within the male poet - a sense that artistic cultivation of the feeling is effeminate and escapist and is opposed to a more vigorous (though less attractive) masculine call to duty."(David, 2005, p.429) In these two poems of Robert Browning, Meeting at Night and Parting at Morning are the embodiment of his double vision about the "effeminate feeling" and "masculine call" by representing "manifested action of the human heart and brain" (David, 2005, p. 432). 


\section{BROWNING's DOUBLE VISION AND MEETING AT NIGHT}

The original poem goes,

Meeting at Night

I. The gray sea and the long black land;

And the yellow half-moon large and low;

And the startled little waves that leap

In fiery ringlets from their sleep,

As I gain the cove with pushing prow,

And quench its speed i' the slushy sand.

II. Then a mile of warm sea-scented beach;

Three fields to cross till a farm appears;

A tap at the pane, the quick sharp scratch

And blue spurt of a lighted match,

And a voice less loud, thro' its joys and fears,

Than the two hearts beating each to each!

Both of the two poems, Meeting at Night and Parting at Morning, are narrative ones, making use of the first-person point of view with the poet as the narrator. In Meeting at Night, the 1st stanza describes the night scenery about the gray sea, the long black land, the yellow half-moon, the large and low (with dim light), and the startled little waves who wake up from their sleep and leap up with joys. The Poet-narrator reaches the small bay with the front of the boat pushing ahead, which stops in the muddy sand. In the 2nd stanza, "I" pass some warm beach which smells of sea and pass some fields and arrive at the farm where "my" lover lives; "I" tap at the pane and she scratches quickly a match and suddenly a blue light flashes; "We" speak at a low voice and it is so low that "we" can hear each other's heart beating.

This is a poem about love, a private matter, "action of human heart" in Browning's words. The poet, though with no use of the word "love" in the poem, has successfully accomplished to convey a "love" experience by presenting a situation - a man going to meet his love despite the physical distance - and describing the situation in terms of sensory impressions. The nature wears emotions, enveloped in darkness, peace, tranquility and harmony. Silence hovers air, which is emphasized by actions of waves and the boat. Nature here is the spiritual vehicle of the poet's state of mind - ecstasy, and excitement. The colors please our eyes and inspire our imaginations. For instance, the blue light against the darkness makes the whole picture beautifully romantic and indicates the romantic passion of this couple. The yellow moon will nourish a sense of warmth and hope in the background of gray sea and black land, standing for the smoothness of the poet in the journey of love. In addition, the lines touch our visual, auditory, tactile and olfactory senses: The use of onomatopoeia like "slush", "tap", "quick sharp scratch" has created unusual effect to indicate the lovers' hurried actions, their eagerness and excitement to see each other. The use of liquid /1/ in "long", "black land", "large and low", "little", "leap" has helped to enchant us in the situation of boat sailing over the dream-like sea. The use of /s/ and /f/ in "sea", "sleep", "slushy sand", "pushing" has helped to render the tranquility of night, echoing the title of the poem. The use of affricate /t $\int /$ in "quench", "beach", "scratch", "match", "each" has brought us with the poet-narrator together to feel about his excitement and ecstasy. All these direct our senses to feel the way the poet feels, to experience what the poet has been going through. "By engaging the reader's senses, the poet is able to attract the reader's attention and convey his feelings on the subject of love." (Laurie, 2006, p. 85)

Not only this, the use of alliteration, internal rhyme and the end rhyme has further created a musical effect; for instance, in the first stanza, "pushing prow", "slushy sand" and "And the yellow half- moon large and low". A more ingenious rhyme is the embraced end rhyme, abccba/ deffed, like in the first stanza "land"/d/, "low"/ou/, "Leap"/p/, "Sleep"/p/, "prow"/əu/, "sand"/d/ and in the second stanza "beach"/i:t $\int /$, "appears"/z/, "scratch"/t $\int /$, "match"/ t $\mathrm{f} /$, "fears"/z/, "each"/i:t $\int /$. This end rhyme symbolizes the lovers' hearts linking for ever as narrated in the last line of the poem "two hearts beating each to each". To look at this rhyme reversely, it implies that the lovers will part for a while and will reunite with each other soon. This will remind us of the poem "Chance" by the Chinese poet Xu Zhimo, "This You and I meet on the sea at night,/You have your direction, and I have mine./If thou wilt, remember,/ or, better still, forget./At the time when we are reunited!" (Xu Yuanchong, 2006, p.98)

In the poem by Browning love is compared to a journey. This connotation is particularly intensified by the symbol "sea". In the poem, the sea seems to be a separating force, standing for the physical distance. And it could also refer to some social taboos or moral conventions about love like the gap in age, the difference in social background, in educational background, in cultural background, in moral principles, etc. In the second stanza, line 1 "warm sea-scented beach", the sea has been endowed with personal emotions: sea, as a separating force, is not the obstacle any more; consequently the poet loaded with joys comes to his lover. It is safe to conclude that sea separates the lovers in geography, but "I" meet "my" lover at night despite the great distance.

The symbolic meaning of sea in this poem corresponds to the literary tradition about the ambiguity of sea serving both as a separating, dangerous resistance and a triumphant, ecstatic strength about the incompatible magic of love. The famous Greek Myth goes in this way: Hero, a priestess of Aphrodite falls in love with a boy Leander across Hellespont. Every night Leander swims across the channel and meets Hero, his lover. One stormy night, he is drowned on the way 
to do so. The following morning his corpse is found on the beach. Overwhelmed with the intense grief, Hero commits suicides to be with Leander forever. Since Hero often holds a lamp to guide Leander to fumble his way in the dark seas, it is said she has turned into a beacon after her death, continuing the same mission, but to guide other sailors.

Yet to Browning, ancient myth serves as a means to achieve his double vision, since "Myth to him is used to make a statement about the nature of life." (Chang, 2006, p.320) He juxtaposes ancient myth with the modern story of love to explore the psychological connotation of the myth. Partly attributed to his pursuit and final rescue of his future wife Miss Elizabeth Barrett, his poetry has a recurrent pattern, as the critic Langbaum puts it, the pattern of "impasse and miracle", where the male hero at the critical moment risks his own life for the lady in jeopardy. In the ancient myth of Leander and Hero, Browning, instead of being confined to the traditional ending for a touching love tragedy, deliberately rewrites the story to cater to the Victorian optimism as well as to testify his persistent efforts toward symbolism and the mystical method in poetic creation for a romantically private vision about human passion and artistic imagination.

Coincidentally, this connotation of sea also refers to ancient Chinese poetry as in Li Zhiyi's poem "I live upstream and you downstream by Yangtze Blue" and in The Book of Poetry, the poem "Where Is She?" in which, she was "Beyond the stream", "On the other side" and "At river's end", "She's far away" and "She's far behind" (Xu Yuanchong, 2006, p.42).

All these love poetry or stories point to the recurring pattern of man's search for his lover across river or sea. Meeting at Night, though not designating the gender of narrator obviously, "I" is normally identified as the male poet, not only because "I" am the one to take this journey as the active "actant" to do, while "she" is passively waiting in her house, but also because that the poem's masculine ending (rhymes that end on a stress) "land", "low", "leap", "sleep", "prow", "sand", "beach", "appears", "scratch", "match", "fears", "each", with the rhyme scheme of "abccba", has been the forceful testimony to the male's perspective. This male "actant" sees the conspicuous expectation of Victorian division between male and female status.

The poet-narrator's journey, however, is engaged in "effeminate feelings". Love is secret, is the first love (It is like Romeo and Juliet. Romeo fell in love with Juliet at the first sight and he could not wait to the next day to express it to Juliet so he came to the window of Juliet and let out his love.), is romance, and is passion. The whole poem presents a world of dream, romance and passion where the feminine temperament is the dominantly permeating force as indicated by the "half-moon". In the moonlight is a blissful world. The moon is feminine, which helps to bring Diana, the goddess of Moon and hunting, into our mind. The goddess is an incarnation of beauty, chastity, prowess, serenity, sanctity, an image of silent warmth and elegance. As a feminine image, it is emotional, too. The medley of female touch and male "actant" definitely create a Browning vision: a private one as an "actant" artist to retreat into the private inner world in search of harmony, peace and established order by means of passionate love.

\section{Browning's Pubic Vision AND PARTING at Morning}

If in Meeting at Night Robert Browning depicts a serenely romantic private vision of love, in contrast, Parting at Morning is one of public duty or commitment, though still with a man's perspective represented by the masculine ending, the "acting" "I" and the image of "sun".

The original poem goes,

Parting At Morning

Round the cape of a sudden cane the sea,

And the sun look'd over the mountain's rim:

And straight was a path of gold for him,

And the need of a world of men for me.

It is interesting to notice that the image used in the second poem is changed from the moon in the first to the sun; the moon is widely acknowledged as being feminine, soft, and dreamy, usually an image standing for women; and for the sun, on the contrary, its image is often associated with the god of Sun Apollo, brother of Diana, who is an incarnation of the intelligence, the strength, the excellence; and an image of reason, activity, as well as light. In this poem the masculine temperament is the prevailing force, which is totally a distinct difference from the previous one. "I", without hesitation and reluctance, all of a sudden, came to the sea round the cape. "I" was on my way back at sunrise. A gold path was straight for the sun. The sun had it. This "Path of gold" points to the sun's movement in the sky from sunrise to sunset in a day, or the sun's one day's work to do. What is more important, it implies "my" promising prospect—a big world out of home, and out of love. It tells clearly that besides love, "I" must engage myself in the worldly affairs and do business with other men; I have ambitions to accomplish. This is a world of business, reason, and reality. Quite differently, for a woman, her world is home and love.

It is an undeniable fact that the Victorian women are more prejudiced in the society. Therefore, the poems of Parting are often the works of male writers. During the Victorian era the role of women was defined largely on the basis of their appearance, and not on intellectual or occupational grounds. It was especially so in the early years of this era. Mary Ann Evans is definitely a case in point: with so much talent for writing, she had to pick up George Eliot, a penname for a man, to approach the readers. The bourgeois woman's identity became connected with the home and she was given the responsibility of creating a genteel atmosphere in which the man could feel in control. The woman, though, had the 
control of the social life of the household: she would arrange the dinners, the tea, and other social situations, at home. (Stenton, 1971, p.270) A stronger ideal of the family and the home was created by a revival of moral reform, paternal authority, and the sexual repression.

Browning, in keeping pace with the zeitgeist of his time, presented in his works an optimistic picture for Victorians. The heroes in his poetry are usually "high man" as he called them, undertaking a mission of rescue or that of high pursuit with their courage and hope. Victorian readers found comfort in his optimistic creed that mortal incompleteness and imperfection only imply an immortal completeness and perfection beyond this life: "On the earth the broken arcs; in the heaven, a perfect round" (Browning, Abt Vogler, lines 433-434)

Hence, there is no wonder that in this second poem, Parting at Morning, he is speaking in this manner: a man of ambition, a man of future, a man of determination, and a man of commitment to fulfill. This is the need of the society, the role a man is supposed to play in front of the public; though possibly it might not be the real inner idea of the narrator for himself, as contrasted by the one reflected in the first poem: Meeting At Night. Like it or not, this is the call of the society then. Thanks to this, we have the double vision.

\section{CONCLUSION}

The Victorian Era to Matthew Arnold is "an age of iron", when for intellectually thinking people the passion in life became altogether "excessively modern". In this age everything appeared to be "sick", so there was a visible nostalgia for a lost world of peace and established order. The middle class, being in charge of the nation's life, enforced their own value system and tastes so that what Matthew Arnold called "cultural philistinism" began to intensify its control and made the life of the mind difficult if it was not extremely impossible. The Victorian Literature was the middle-class, urban literature. For Matthew Arnold, his division is between his commitment and private vision. He believes that the poet is to move people to participate and take the burden of life and humanity willingly.

Double division is not hard to find in the works of other writers of the same age also. In The Mill on the Floss, in the last scene the brother and sister get redemption through baptism; both are sinned and are reborn. This well demonstrates to the audience that there is the double self of George Eliot. As a Victorian woman she supports the moral duty to give punishment to Maggie, for the sake of the public image; yet as a novelist, she has her private vision to lavish love on the image of Maggie, for the sake of her own.

Also, Robert Louis Stevenson's novel The Strange Case of Dr. Jekyll and Mr. Hyde (1886) takes a look inside "the haunted house of Victorian culture", and this tale of the homo duplex - the man split between a respectable public self and a hidden, violent and animal double - was a fable that touched some of the deeper moral anxieties of its historical age. The book's essential message is "Man is not truly one, but truly two" (Chang, 2006, p.307): Jekyll, seeking to separate his good side from his darker impulses, discovered a way to transform himself periodically into a creature free of conscience, this being Mr. Hyde. The transformation was incomplete, however, in that it created a second and evil identity, but did not make the first identity purely good. At first, Jekyll reported, he delighted in becoming Hyde and rejoiced in the moral freedom that the creature possessed. Yet eventually, he found that he was turning into Hyde involuntarily in his sleep, even without taking the potion. At this point, Jekyll resolved to cease becoming Hyde. He ends his letter saying "I bring the life of that unhappy Henry Jekyll to an end". With these words, both the document and the novel come to a close.

And, the theme of doubled self in the doubled city made its appearance in its Decadent form in Oscar Wilde's The Picture of Dorian Gray (1891), where the ambiguity is brought into the center of the art itself. In Wilde's version, Dorian becomes ever more corrupt in life, but holds on to his golden youth. Meanwhile his portrait in the attic ages and decays, with the art expressing the reality as the reality turns into art. The portrait becomes the double; when it must be destroyed ("It had been like a conscience to him... He would destroy it"), Dorian himself ages and dies. Dorian in The Picture of Dorian Gray is both the criminal and the aesthete combined in one man. This is perhaps linked to Robert Louis Stevenson's Strange Case of Dr. Jekyll and Mr. Hyde, which Wilde admired so much. The division that was witnessed in Dr. Jekyll and Mr. Hyde, though extreme, is evident in Dorian Gray, who attempts to contain the two divergent parts of his personality. This is also a recurring theme in many Gothic novels.

"Victorian era was one in which man became well aware that life was increasing its encroachment upon his spiritual wholeness, and that his consciousness and his unconscious, his intellect and his imagination, his external world and his inner world were all at work to divide him into two halves." (Chang, 2006, p.320) Robert Browning, a sensitive mind to this era, feels that he is in an incompatible contradiction, tug between his pubic commitment as a man of Victorian Era, following the values and convention of this particular historical period, and his private vision as a poet who is honest to his heart, between his supposed duty for spreading the middle-class values then and his hidden desire for a passionate loving relationship, between his flesh and his soul. What is worthy of attention is that he goes even to the delicate level of psychology, the dramatic monologue has done its job for reflecting the inner mind of the narrator's: in the first one, love overpowers all and nothing can interfere with it, for love, he is ready to do anything; then he goes back to the world of reality, distorting his real ideas.

"Victorian poetry is characteristically dialogic, presupposing, and even harboring the existence of multiple choices." (Linda, 2010, "Introducing Victorian Poetry", p.7) "It is the body,... of the poem, while the proliferating symbols and metaphors, bespeak its soul. In this sense, too, the poem enacts as double vision." (Linda, 2010, p.274) This general 
statement exactly can be used to summarize Robert Browning's poetic creation. He works as a Romantic poet and a Victorian story-teller, articulating a double vision that embodies and narrates the compelling importance of poetry, social justice and erotic relations.

\section{REFERENCES}

[1] Baldick, Chris. (2001). Oxford Concise Dictionary of Literary Terms, Shanghai: SFLEP.

[2] Chang Yaoxin. (2006). A Survey of English Literature, Tianjin: Nankai University Press.

[3] David G. Riede. (2005). "The Victorian Era", from Carl Woodring \& James Shapiro, ed. The Columbia History of British Poetry, Beijing: FLTRP \& Columbia University Press.

[4] Laurie E Rozakis. (2006). Chen Bing ed., How to Interpret Poetry, Shanghai: Shanghai Translation Publishing House.

[5] Linda, K. Hughes. (2010). The Cambridge Introduction to Victorian Poetry, Cambridge: Cambridge University Press.

[6] Stenton, F.M. (1971). Anglo-Saxon England, 3rd ed., Oxford: Oxford University.

[7] Xu Yuanchong. (2006). Selections from the Book of Poetry, Beijing: China Intercontinental Press.

Lihua Zhang was born in Shandong, China in 1979. She received her master degree in linguistics from Xiamen University, China in 2003.

She is currently a lecturer in the School of Foreign Languages, Beijing Institute of Technology, Beijing, China. Her research interests include English Teaching and Applied Linguistics. 